\title{
INFLUENCE OF FOLIAR SPRAYS OF DIFFERENT POTASSIUM FERTILIZERS ON YIELD AND FRUIT QUALITY OF BALADY MANDARIN TREES
}

\author{
H. A. Ennab and A. M. A. Khedr \\ Citrus Research Department, Horticulture Research Institute, Agriculture Research \\ Center, Giza, Egypt
}

Received: Mar. 4, 2021

Accepted: Mar. 15, 2021

\begin{abstract}
The present study was carried out on twenty years old Balady mandarin trees grown in a private orchard at Motobus, Kafr El-Sheikh governorate, Egypt during 2019 and 2020 seasons to study the effect of foliar application of different potassium forms i.e. potassium sulphate, potassium humate and potassium silicate at 2, 3 and $4 \mathrm{~g} / \mathrm{l}$ on nutritional status, yield and fruit quality. Each potassium source was applied in three times at 15 April, 20 May and 24 June. The results showed that potassium sprays especially potassium silicate at $4 \mathrm{~g} / \mathrm{l}$ had a positive effect on nitrogen, phosphorus, potassium percentages, total carbohydrate and total chlorophyll content in the leaves, which reflected on enhanced yield and fruit physical and chemical characteristics compared to control and other treatments. It could be recommended that spraying Balady mandarin trees with potassium silicate at $4 \mathrm{~g} / \mathrm{l}$ three times beginning of 15 April 20 May and 24 June for improve leaves nutritional status and enhance yield and fruit physical and chemical characteristics.
\end{abstract}

Key words: Citrus, yield, silicate, humate, chlorophyll, firmness, ascorbic acid

\section{INTRODUCTION}

Mandarins (Citrus reticulata, Blanco) are one of the most popular fruit among citrus in Egypt, due to its high yield, fresh consumption, easy peeling and acceptable juice quality as well as nutritive value (Ennab et al., 2017). Planted area of mandarins reached 108,134 feddan, represented about $22.5 \%$ of total area of citrus $(479,655$ feddan), and produce 977,885 ton represented about $22.6 \%$ of the total citrus production $(4,323,030$ ton) according to Anonymous (2019).Tree nutrition is one of the most important inputs for enhancing growth, reproductive behavior and to ensure high productivity with a good quality of citrus fruits (Iglesias et al., 2007). Potassium is one of the essential elements for plant nutrition, in this respect citrus trees needs to potassium in large amounts (Alva et al., 2001). Where, potassium plays a major role in: photosynthesis, translocation of photosynthates compounds, protein synthesis, control of ionic balance, regulation of plant stomata, water use, activation of plant enzymes and many others processes (Alva et al., 2006 and Kumar et al., 2006). Moreover, this cation is an important one for increasing yield and improves fruit size, color and flavor of mandarin trees (Ashraf et al., 2010). In this respect, Quaggio et al., (2011) evaluated the effect of two $\mathrm{K}$ forms $\left(\mathrm{K}_{2} \mathrm{SO}_{4}\right.$ and $\left.\mathrm{KCl}\right)$ at 0,100 , 200 and $300 \mathrm{~kg} / \mathrm{ha}$ on yield and fruit quality of Pera and Valencia oranges and found that yield increased with increasing $K$ doses and total soluble solids was decrease. Also, Hamza et al., (2015) evaluated two forms of potassium with different levels $\left(\mathrm{KNO}_{3}\right.$ at 0,5 and $8 \%$ and $\mathrm{K}_{2} \mathrm{SO}_{4}$ at 2.5 and $4 \%$ ) to verify their effect on fruit characteristics. It was concluded that foliar application of potassium regardless the source used, increased fruit weight, size, color, 
firmness and rind thickness as well as there was a slight increase in acidity percentage and total soluble solids associated to potassium application. Furthermore, under abiotic stress conditions as salinity, drought and heat stress, potassium may contribute to reduce excess absorption of sodium and chloride by citrus trees (Hasanuzzaman et al., 2018). One of the mechanisms for improving plant tolerance to stresses is to apply potassium, which seems to have beneficial effects mitigate the adverse effects of stresses by increasing translocation and maintaining water balance within plants (Wang et al., 2013).

Therefore, this investigation was conducted to study the effect of foliar sprays of potassium silicate, potassium humate and potassium sulphate at different levels on nutritional status, yield and fruit quality of Balady mandarin trees.

\section{MATERIALS AND METHODS}

A field experiment was conducted on twenty years old Balady mandarin trees (Citrus reticulata, Blanco) budded on sour orange (Citrus aurantium L.) rootstock, and planted at $5 \times 5 \mathrm{~m}$ spacing in a private orchard located at Motobus, Kafr El-Sheikh governorate, Egypt, during 2019 and 2020 seasons. The soil texture was clay $(60.56 \%$ clay, $21.14 \%$ silt and $18.30 \%$ sand), $1.15 \%$ organic mater, $1.48 \mathrm{dSm}^{-1}$ an electrical conductivity and a $\mathrm{pH}$ of 8.00. All trees received the same cultural practices and the following soil fertilization program; 1000:250:500 NPK $\mathrm{g} /$ tree/year applied as $4.85 \mathrm{~kg} / \mathrm{tree}$ ammonium sulphate $(20.6 \% \quad \mathrm{~N}), 1.60$ $\mathrm{kg} /$ tree super phosphate $\left(15.5 \% \quad \mathrm{P}_{2} \mathrm{O}_{5}\right)$ and $1.00 \mathrm{~kg} /$ tree potassium sulphate $(48 \%$ $\mathrm{K}_{2} \mathrm{O}$ ). Nitrogen fertilizer was added on three doses, at March, the first of June and at the end of August; potassium fertilizer was applied on two doses, at the first of March and at the end of August with nitrogen fertilization. All fertilizers added as broadcast on the soil surface through the whole area.Thirty trees uniform in growth, vigor and productivity were selected, and arranged in a randomized complete block design, each treatment replicated three times with one tree for each replicate. The experiment included ten treatments as follows; control (sprayed with tap water) in addition to potassium sulphate $(48 \%$ $\left.\mathrm{K}_{2} \mathrm{O}\right)$, potassium humate $\left(10 \% \mathrm{~K}_{2} \mathrm{O}\right)$ and potassium silicate $\left(10.25 \% \mathrm{~K}_{2} \mathrm{O}\right)$ at three concentrations i.e. 2, 3 and $4 \mathrm{~g} / \mathrm{l}$. The trees were sprayed three times beginning of 15 April, 20 May and 24 June by solution 10 liters/tree using a handheld sprayer until runoff in the early morning.The following data was recorded:

\section{Nutritional status:}

In the second week of August, twenty mature leaves were sampled from each replicate to determine total chlorophylls, total carbohydrate and leaf NPK content as follows: Total chlorophylls in fresh leaf samples were determined by using chlorophyll Meter model SPAD 502 according to Netto et al., (2005). The remaining leaf samples were dried at $\mathbf{7 0}$ ${ }^{\circ} \mathrm{C}$ to a constant weight, and then $0.5 \mathrm{~g}$ powder from dried leaves was taken to determine total carbohydrate according to Doubis et al., (1956), then $\mathrm{C} / \mathrm{N}$ ratio was calculated. Dried leaves were grounded and digested with $\mathrm{H}_{2} \mathrm{SO}_{4}$ and $\mathrm{H}_{2} \mathrm{O}_{2}$ according to Evenhuis and Dewaard (1980). In digested solution samples nitrogen, phosphorus and potassium were determined as: nitrogen was determined by micro-Kjeldahl method (A.O.A.C. 1990), Phosphorus was determined coloremetrically as described by Murphy and Riley (1962) and Potassium was estimated by using flame photometer as described by Brown and Lillelland (1974). 


\section{Yield:}

Yield was harvested at December $15^{\text {th }}$ and $19^{\text {th }}$ in 2019 and 2020 seasons, respectively. Yield of each replicate was determined as $\mathrm{kg} /$ tree and total yield as ton/feddan.

\section{Fruit quality:}

To determine fruit quality, 20 healthy fruits were taken at random from each tree at harvest time of both seasons and prepared for determination of physical and chemical fruit quality assessment according to A.O.A.C., (1990). Fruit characters were fruit weight $(g)$, fruit volume $(\mathrm{ml})$, fruit length $(\mathrm{cm})$, and diameter $(\mathrm{cm})$, peel thickness $(\mathrm{mm})$, fruit firmness was measured $\left(\mathrm{lb} / \mathrm{in}^{2}\right)$ on the two opposite sides of fruit using Effigi pressure tester at the tropic of the fruit (mod. Ft 327) and the values of readings were converted to Newton unit $\left(\mathrm{Ib} / \mathrm{in}^{2} \times\right.$ 4.448), fruit juice \%., total soluble solid (TSS) was determined by handy refractometer, titratable acidity was determined as citric acid, ascorbic acid as $\mathrm{mg} / 100 \mathrm{ml} / \mathrm{juice}$ by using 2,6 dichlorophenol indophenol and TSS/acid ratio was calculated.

\section{Statistical analysis:}

The obtained data were subjected to analysis of variance according to Snedecor and Cochran (1990). Duncan's multiple range test (Duncan, 1955) at $5 \%$ level was used to compare the mean values.

\section{RESULTS AND DISCUSSION}

\section{Nutritional status:}

\subsection{Leaf NPK content:}

Results in Table 1 revealed that the concentrations of $N, P$ and $K$ in the leaves of Balady mandarin trees were significantly influenced by spraying with potassium sulfate, potassium silicate and potassium humate as compared with control treatment in both seasons. The highest concentration of nitrogen in leaves of Balady mandarin recorded with foliar application of potassium silicate and potassium humate at $4 \mathrm{~g} / \mathrm{l}$ in both seasons, respectively without significant differences between them. Meanwhile, the lowest concentration of nitrogen was observed in leaves taken from trees sprayed by tap water (control) in both seasons. As for phosphorus, data showed that spraying with potassium humate in the first season and potassium silicate at $4 \mathrm{~g} / \mathrm{l}$ in the second season produced the highest concentration of phosphorus followed by potassium humate at $3 \mathrm{~g} / \mathrm{l}$ in both seasons. On the other hand, spraying with tap water (control) gave the lowest values of leaf phosphorus content in both seasons. With regard to potassium, data revealed that spraying Balady mandarin trees with potassium humate and potassium silicate at $4 \mathrm{~g} / \mathrm{l}$ produced the highest values of potassium concentration in leaves in both seasons without significant differences between them. In contrast, the lowest concentration of potassium was observed in leaves taken from tree sprayed with tap water (control) in both seasons. These results agree with those obtained by El-Salhy et al., (2017) and Reetika et al., (2020) on Balady and Kinnow mandarins, respectively. In this respect, Aly et al., (2011) revealed that Balady mandarin trees sprayed with different potassium forms such potassein at $0.7 \%$ and Vinasse at $10 \%$ led to increasing level of $N, P$ and $K$ in leaves especially under Vinasse. Also, Sarrwy et al., (2012) reported that Balady mandarin trees sprayed with potassium nitrate, mono potassium phosphate and potassium thiosulfate each at 1 and $1.5 \%$ gave the higher values of $N, P$ and $K$ contents in leaves than that on control, and also concluded that potassium nitrate gave the best results in this respect as compared with the other 
potassium forms. Moreover, Abo ElEnien et al., (2017) concluded that foliar application of potassium silicate at $2 \mathrm{~g} / \mathrm{l}$ tended to improve leaf $N, P$ and $K$ contents in Valencia orange seedlings.

\subsection{Leaf Chlorophylls, carbohydrates and $\mathrm{C} / \mathrm{N}$ ratio contents:}

The results in Table 2 show that foliar spraying with potassium sulfate, potassium silicate and potassium humate at various rates significantly increased total chlorophylls, total carbohydrates \% and $\mathrm{C} / \mathrm{N}$ ratio in leaves of Balady mandarin trees compared with control treatment in both seasons. As for total chlorophylls, it is clear that spraying Balady mandarin trees with potassium silicate at 4 and $3 \mathrm{~g} / \mathrm{l}$ gave the highest content of total chlorophyll followed by potassium humate at $4 \mathrm{~g} / \mathrm{l}$ in both seasons, respectively. In contrary, the lowest values of total chlorophyll found in trees of control treatment and potassium sulphate at $2 \mathrm{~g} / \mathrm{l}$ in the first season and control treatment only in the second season, respectively. The positive effect of foliar application of different forms of potassium on total chlorophyll was reported by El-Saady and El-Abd (2012) \& Zaghloul and Knany (2012) on navel oranges. In this respect, Mostafa and Saleh (2006) cleared that spraying potassium using different forms had a positive effect on total chlorophyll content in leaves of Balady mandarin trees especially potassium nitrate at $2 \%$. Regarding total carbohydrate \%, it is observed from data in Table 2 that, total carbohydrates were positively affected by using different potassium forms; and in this respect Balady mandarin trees sprayed with potassium silicate at $4 \mathrm{~g} / \mathrm{l}$ recorded the highest values of total carbohydrate followed by potassium humate at $4 \mathrm{~g} / \mathrm{l}$ and potassium silicate at $3 \mathrm{~g} / \mathrm{l}$ in both seasons, respectively with significant differences among them. The lowest values of total carbohydrate content were observed in trees sprayed with tap water (control).

Table 1: Effect of foliar application of different potassium forms on leaf NPK contents of Balady mandarin trees

\begin{tabular}{|c|c|c|c|c|c|c|c|}
\hline \multirow{2}{*}{ Treatments } & & \multicolumn{2}{|c|}{ Nitrogen\% } & \multicolumn{2}{|c|}{ Phosphorus\% } & \multicolumn{2}{|c|}{ Potassium\% } \\
\hline & & 2019 & 2020 & 2019 & 2020 & 2019 & 2020 \\
\hline \multicolumn{2}{|c|}{ Control (tap water) } & $2.08 \mathrm{~h}$ & $2.14 \mathrm{~g}$ & $0.35 \mathrm{~h}$ & $0.36 f$ & $1.52 \mathrm{~h}$ & $1.63 \mathrm{~g}$ \\
\hline Potassium & $2 \mathrm{~g} / \mathrm{l}$ & $2.19 \mathrm{~g}$ & $2.15 \mathrm{~g}$ & $0.36 \mathrm{~g}$ & $0.38 \mathrm{e}$ & $1.58 \mathrm{~g}$ & $1.65 \mathrm{fg}$ \\
\hline \multirow[t]{2}{*}{ sulphate } & $3 \mathrm{~g} / \mathrm{l}$ & $2.33 \mathrm{f}$ & $2.30 \mathrm{f}$ & $0.37 \mathrm{f}$ & $0.38 \mathrm{e}$ & $1.70 \mathrm{f}$ & $1.69 \mathrm{f}$ \\
\hline & $4 \mathrm{~g} / \mathrm{l}$ & $2.39 \mathrm{e}$ & $2.36 \mathrm{e}$ & $0.37 \mathrm{f}$ & $0.38 \mathrm{e}$ & $1.79 \mathrm{e}$ & $1.77 \mathrm{e}$ \\
\hline Potassium & $2 \mathrm{~g} / \mathrm{l}$ & $2.56 \mathrm{c}$ & $2.63 \mathrm{~d}$ & $0.40 \mathrm{~d}$ & $0.41 \mathrm{c}$ & $1.87 \mathrm{~d}$ & $1.82 \mathrm{~cd}$ \\
\hline \multirow[t]{2}{*}{ silicate } & $3 \mathrm{~g} / 1$ & $2.65 \mathrm{~b}$ & $2.76 \mathrm{bc}$ & $0.40 \mathrm{~d}$ & $0.41 \mathrm{c}$ & $1.91 \mathrm{c}$ & $1.91 \mathrm{~b}$ \\
\hline & $4 \mathrm{~g} / \mathrm{l}$ & $2.78 \mathrm{a}$ & $2.83 \mathrm{a}$ & $0.44 \mathrm{c}$ & $0.46 a$ & $1.97 \mathrm{a}$ & $2.00 \mathrm{a}$ \\
\hline Potassium & $2 \mathrm{~g} / \mathrm{l}$ & $2.50 \mathrm{~d}$ & $2.59 \mathrm{~d}$ & $0.39 \mathrm{e}$ & $0.40 \mathrm{~d}$ & $1.81 \mathrm{e}$ & $1.78 \mathrm{de}$ \\
\hline \multirow[t]{2}{*}{ humate } & $3 \mathrm{~g} / \mathrm{l}$ & $2.59 \mathrm{c}$ & $2.73 \mathrm{c}$ & $0.45 \mathrm{~b}$ & $0.44 \mathrm{~b}$ & $1.89 \mathrm{~cd}$ & $1.86 \mathrm{c}$ \\
\hline & $4 \mathrm{~g} / \mathrm{l}$ & $2.77 \mathrm{a}$ & $2.80 \mathrm{ab}$ & $0.47 a$ & $0.44 \mathrm{~b}$ & $1.95 \mathrm{ab}$ & $1.96 \mathrm{a}$ \\
\hline
\end{tabular}

Means followed by different letter are significantly different within columns by Duncan's multiple range test, $P \leq 0.05$. 
Table 2: Effect of foliar application of different potassium forms on leaf chlorophyll, carbohydrates and $\mathrm{C} / \mathrm{N}$ ratio contents of Balady mandarin trees

\begin{tabular}{lccccccc}
\hline \multirow{2}{*}{ Treatments } & \multicolumn{2}{c}{ Chlorophylls } & (SPAD) & \multicolumn{2}{c}{ Carbohydrate \% } & \multicolumn{2}{c}{ C/N ratio } \\
\cline { 2 - 8 } & & 2019 & 2020 & 2019 & 2020 & 2019 & 2020 \\
\hline \multicolumn{2}{l}{ Control (tap water) } & $39.50 \mathrm{f}$ & $40.70 \mathrm{~h}$ & $8.58 \mathrm{i}$ & $8.87 \mathrm{i}$ & $4.12 \mathrm{~d}$ & $4.14 \mathrm{e}$ \\
Potassium & $2 \mathrm{~g} / \mathrm{l}$ & $39.55 \mathrm{f}$ & $41.30 \mathrm{~g}$ & $9.30 \mathrm{~h}$ & $9.63 \mathrm{~h}$ & $4.24 \mathrm{~d}$ & $4.48 \mathrm{bcd}$ \\
sulphate & $3 \mathrm{~g} / \mathrm{l}$ & $40.17 \mathrm{ef}$ & $41.72 \mathrm{f}$ & $9.91 \mathrm{~g}$ & $10.26 \mathrm{~g}$ & $4.25 \mathrm{~cd}$ & $4.45 \mathrm{bcd}$ \\
& $4 \mathrm{~g} / \mathrm{l}$ & $41.40 \mathrm{~cd}$ & $42.77 \mathrm{~d}$ & $10.30 \mathrm{f}$ & $10.85 \mathrm{f}$ & $4.30 \mathrm{~cd}$ & $4.60 \mathrm{bc}$ \\
Potassium & $2 \mathrm{~g} / \mathrm{l}$ & $41.23 \mathrm{~cd}$ & $42.68 \mathrm{~d}$ & $10.99 \mathrm{e}$ & $11.57 \mathrm{e}$ & $4.29 \mathrm{~cd}$ & $4.39 \mathrm{cde}$ \\
silicate & $3 \mathrm{~g} / \mathrm{l}$ & $43.00 \mathrm{~b}$ & $44.44 \mathrm{~b}$ & $11.80 \mathrm{c}$ & $12.35 \mathrm{C}$ & $4.45 \mathrm{bc}$ & $4.47 \mathrm{bcd}$ \\
& $4 \mathrm{~g} / \mathrm{l}$ & $43.94 \mathrm{a}$ & $45.41 \mathrm{a}$ & $13.42 \mathrm{a}$ & $13.87 \mathrm{a}$ & $4.82 \mathrm{a}$ & $4.90 \mathrm{a}$ \\
Potassium & $2 \mathrm{~g} / \mathrm{l}$ & $40.77 \mathrm{de}$ & $42.14 \mathrm{e}$ & $10.32 \mathrm{f}$ & $10.96 \mathrm{f}$ & $4.13 \mathrm{~d}$ & $4.23 \mathrm{de}$ \\
humate & $3 \mathrm{~g} / \mathrm{l}$ & $41.73 \mathrm{C}$ & $43.65 \mathrm{C}$ & $11.51 \mathrm{~d}$ & $12.05 \mathrm{~d}$ & $4.44 \mathrm{bc}$ & $4.41 \mathrm{~cd}$ \\
& $4 \mathrm{~g} / \mathrm{l}$ & $42.60 \mathrm{~b}$ & $44.55 \mathrm{~b}$ & $12.61 \mathrm{~b}$ & $13.16 \mathrm{~b}$ & $4.55 \mathrm{~b}$ & $4.70 \mathrm{ab}$ \\
\hline
\end{tabular}

Means followed by different letter are significantly different within columns by Duncan's multiple range test, $\mathrm{P} \leq 0$.

These results are in harmony with those of Mostafa and Saleh (2006) and ElSalhy et al., (2017) on Balady mandarin trees. With regard to $\mathrm{C} / \mathrm{N}$ ratio, data revealed that foliar spraying with different forms of potassium had significantly increased leaf contents of $\mathrm{C} / \mathrm{N}$ ratio compared to control treatment. The maximum $\mathrm{C} / \mathrm{N}$ ratio was recorded in leaves of trees that sprayed by potassium silicate followed by potassium humate with concentration of $4 \mathrm{~g} / \mathrm{l}$ in both seasons. Similar results were obtained by El-Salhy et al., (2017) on Balady mandarin trees. Generally, it is obvious from Tables 1 and 2 that, leaf contents of NPK, total chlorophyll, total carbohydrate and $\mathrm{C} / \mathrm{N}$ ratio weresignificantly enhanced by foliar sprays with the different forms of potassium in both seasons. In this respect, leaves of Balady mandarin trees sprayed with potassium silicate followed by potassium humate had higher values of NPK, total chlorophyll, total carbohydrate and $\mathrm{C} / \mathrm{N}$ ratio than that on potassium sulphate; it means that foliar spraying with potassium silicatewas more effective in improving the nutritional status of Balady mandarin trees under the clay soil conditions. Furthermore, the concentrations of nitrogen, phosphorus, potassium, carbohydrate and amounts of chlorophyll, and $\mathrm{C} / \mathrm{N}$ ratio in leaves are proportional with concentration of potassium, this means NPK, chlorophyll, carbohydrate and $\mathrm{C} / \mathrm{N}$ ratio were increased with increasing the concentration of potassium especially spraying potassium silicate and potassium humate at $4 \mathrm{~g} / \mathrm{l}$. The positive effect of foliar spraying with potassium silicate or potassium humate on nutritional status of mandarin trees may be due to the favorable effect of potassium, silicon and humatein enhanced nutrients uptake especially nitrogen, and/or they causes abiotic effects on plant which induces the plants to accumulate organic ions. These explanations agree with our data in Tables 1 and 2 and Mostafa and Saleh (2006) who revealed that spraying potassium at different forms had a positive effect on nitrogen and potassium percentages, total carbohydrate and total chlorophyll in the leaves of Balady mandarin trees, which reflected on increasing fruit weight, number of fruits per tree and finally yield weight per tree.

\section{Yield:}

The results in Table 3 indicated that foliar spraying with different potassium 
forms significantly increased fruit weight and yield ( $\mathrm{kg} /$ tree or ton/feddan) of Balady mandarin trees as compared to control treatment in both seasons. In addition, spraying with potassium silicate treatments gave the best results as for fruit weight and yield followed by potassium humate treatments and finally potassium sulphate treatments in both seasons. Moreover, fruit weight and yield were significantly increased with increasing the levels of potassium from 1 to $3 \mathrm{~g} / \mathrm{l}$ under the same source of potassium. The maximum yield and heaviest fruits were recorded in the trees that sprayed with potassium silicate followed by potassium humate at $4 \mathrm{~g} / \mathrm{l}$ with significant differences between them in both seasons, except yield in the first season only. In contrary, the lowest values of yield and fruit weight were observed in trees sprayed with tap water (control). These results are in agreement with Shen et al., (2016) and El-Mahdy et al., (2019) on pear and orange. Also, Vijay et al., (2017) on Jaffa sweet orange indicated that spraying different levels of potassium nitrate and sulphate had positive effects on improving fruit weight and increasing yield especially potassium nitrate at $4 \%$. In this respect, Mostafa and Saleh (2006) \& Aly et al., (2011) found that spraying Balady mandarin trees with some potassium forms led to improved fruit weight and increasing yield. Moreover, Ashraf et al., (2010) and Aly et al., (2011) found that mandarin fruit weight and yield as number of fruits/tree or as weight $(\mathrm{Kg} / \mathrm{tree})$ were increased and reached to maximum by spraying with potassium. The positive effect of foliar application of different forms of potassium specially potassium silicate and humate treatments on fruit weight and yield may be due to the significant absorption of NPK nutrients (Table 1), the pronounced positive effects on leaf chlorophyll and carbohydrate contents as well as $\mathrm{C} / \mathrm{N}$ ratio (Table 2) which leads to healthy trees with a good nutritional status and hence improve fruit weight and increasing yield. These explanations agree with Kumar et al., (2006) and Quaggio et al., (2011).

Table 3: Effect of foliar application of different potassium forms on yield of Balady mandarin trees

\begin{tabular}{|c|c|c|c|c|c|c|c|}
\hline \multirow{3}{*}{ Treatments } & & \multicolumn{4}{|c|}{ Yield } & \multirow{2}{*}{\multicolumn{2}{|c|}{$\begin{array}{c}\text { Fruit weight } \\
\text { (g) }\end{array}$}} \\
\hline & & \multicolumn{2}{|c|}{$\mathrm{Kg} /$ tree } & \multicolumn{2}{|c|}{ ton/feddan } & & \\
\hline & & 2019 & 2020 & 2019 & 2020 & 2019 & 2020 \\
\hline \multicolumn{2}{|c|}{ Control (tap water) } & $38.64 \mathrm{~h}$ & $42.03 j$ & $6.49 i$ & $7.06 \mathrm{j}$ & $129.85 \mathrm{~g}$ & $132.91 \mathrm{~h}$ \\
\hline \multirow{3}{*}{$\begin{array}{l}\text { Potassium } \\
\text { sulphate }\end{array}$} & $2 \mathrm{~g} / \mathrm{l}$ & $42.41 \mathrm{~g}$ & $45.34 \mathrm{i}$ & $7.11 \mathrm{~h}$ & $7.61 i$ & $131.00 \mathrm{f}$ & $135.75 \mathrm{~g}$ \\
\hline & $3 \mathrm{~g} / \mathrm{l}$ & $45.16 \mathrm{f}$ & $48.54 \mathrm{~h}$ & $7.58 \mathrm{~g}$ & $8.14 \mathrm{~h}$ & $133.93 e$ & $138.92 \mathrm{f}$ \\
\hline & $4 \mathrm{~g} / \mathrm{l}$ & 48.22 e & $51.33 \mathrm{~g}$ & $8.09 \mathrm{f}$ & $8.61 \mathrm{~g}$ & $138.49 \mathrm{c}$ & $141.44 \mathrm{e}$ \\
\hline \multirow{3}{*}{$\begin{array}{l}\text { Potassium } \\
\text { silicate }\end{array}$} & $2 \mathrm{~g} / \mathrm{l}$ & $53.81 \mathrm{c}$ & $54.36 \mathrm{e}$ & $9.04 \mathrm{de}$ & $9.13 \mathrm{e}$ & $139.19 \mathrm{c}$ & $144.05 \mathrm{~d}$ \\
\hline & $3 \mathrm{~g} / \mathrm{l}$ & $56.61 \mathrm{~b}$ & $57.24 \mathrm{c}$ & $9.51 b c$ & $9.61 \mathrm{c}$ & $139.46 \mathrm{c}$ & $145.20 \mathrm{c}$ \\
\hline & $4 \mathrm{~g} / \mathrm{l}$ & 59.93 a & $63.71 \mathrm{a}$ & $10.06 \mathrm{a}$ & $10.70 \mathrm{a}$ & $145.16 \mathrm{a}$ & 149.13 a \\
\hline \multirow{3}{*}{$\begin{array}{l}\text { Potassium } \\
\text { humate }\end{array}$} & $2 \mathrm{~g} / \mathrm{l}$ & $51.57 \mathrm{~d}$ & $52.53 \mathrm{f}$ & $8.66 \mathrm{e}$ & $8.82 f$ & $136.25 \mathrm{~d}$ & $142.22 \mathrm{e}$ \\
\hline & $3 \mathrm{~g} / \mathrm{l}$ & $55.46 \mathrm{bc}$ & $56.80 \mathrm{~d}$ & $9.31 \mathrm{~cd}$ & $9.54 \mathrm{~d}$ & $138.49 \mathrm{c}$ & $144.32 \mathrm{~d}$ \\
\hline & $4 \mathrm{~g} / \mathrm{l}$ & 58.57 a & $61.61 \mathrm{~b}$ & $9.83 \mathrm{~b}$ & $10.35 b$ & $142.74 b$ & $146.40 \mathrm{~b}$ \\
\hline
\end{tabular}

Means followed by different letter are significantly different within columns by Duncan's multiple range test, $P \leq 0.05$. 


\section{Fruit quality:}

\subsection{Physical characteristics:}

Data presented in Tables 4 and 5 shows the effect of foliar application of different forms and levels of potassium on physical fruit characters in terms of length, diameter, volume, firmness, peel thickness and juice (\%) of Balady mandarin trees in both seasons. With regard to fruit length, diameter and volume, the results in Table 4 clearly showed that foliar spraying with different potassium forms and concentrations significantly increased fruit length, diameter and volume compared to control treatment in both seasons. Also, fruit length, diameter and volume were significantly increased by foliar application of potassium silicate, potassium humate and potassium sulphate compared to the control in both seasons. In this respect, potassium silicate at 4 and $3 \mathrm{~g} / \mathrm{l}$ produced the longest, widths and largest fruits than other treatments in both seasons. On contrary, trees sprayed with tap water (control) gave the lowest values of fruit length, diameter and volume during both studied seasons. These results are in agreement with those found by Shaaban et al., (2012) and Taha et al., (2014). In this respect, Ashraf et al., (2010) stated that fruit size increased with increasing potassium supply. Also, Shen et al., (2016) reported that potassium nitrate, phosphate and humate had a positive impact on increasing fruit weight and size. As for fruit firmness, peel thickness and fruit juice (\%), data in Table 5 revealed that with respect to peel thickness, there were no significant differences among the forms and levels of potassium in both seasons, from the statistical view. Meanwhile, potassium silicate at 4 and $3 \mathrm{~g} / \mathrm{l}$ recorded the highest value of peel thickness as compared with control and other treatments in both seasons. With regard to fruit firmness and fruit juice content, the results indicated that to fruit firmness and fruit juice content were significantly increased by different potassium forms in both seasons. The highest significant value was recorded with potassium silicate at 4 and $3 \mathrm{~g} / \mathrm{l}$ in both studied seasons. On the other contrary, control treatment recorded the lowest value in this respect. The present results are in harmony with the findings of Aly et al., (2011), Sarrwy et al., (2012) and El-Salhy et al., (2017). This can be explained by the role of potassium and silicon which plays an important role in carbohydrates metabolism and enzymes activity, affecting fruit quality, and increase fruit weight and size and firmness (Quaggio et al., 2011).

\subsection{Chemical characteristics:}

The results in Table 6 and Figure 1 clearly showed that foliar spraying with different potassium forms and levels significantly increased total soluble solids percentage, acidity and vitamin C in both seasons. In the first season, potassium silicate, potassium humate and potassium sulphate $(4 \mathrm{~g} / \mathrm{l})$ were raising total soluble solids percentage as compared with the control treatment, but there was no significant differences among the forms and levels of potassium in the first season. Meanwhile, in the second season, potassium silicate at 4 and $3 \mathrm{~g} / \mathrm{l}$ recorded the highest value of total soluble solids percentage as compared with control and other treatments in both seasons. Concerning fruit acidity, it is clear that spraying potassium sulphate at 4 and $3 \mathrm{~g} / \mathrm{l}$ gave the highest content of acidity followed by potassium humate at $4 \mathrm{~g} / \mathrm{l}$ in both seasons, respectively. In contrary, the lowest values of total acidity found in fruits taken from trees sprayed with control treatment in both seasons. As for TSS/acid ratio, tree treated with tap water 
(control) produced fruits have the highest values of TSS/acid ratio followed by potassium silicate at 4,3 and $2 \mathrm{~g} / \mathrm{l}$ without significant differences among them in both seasons, respectively. Regarding vitamin C it is clear from data in Figure 1 that vitamin $C$ was significantly increased by all different treatments of potassium compared to control treatment. Spraying with potassium silicate at 4,3 and $2 \mathrm{~g} / \mathrm{l}$ gave the highest valuesof vitamin $C$ of in both seasons. On the other side, control treatment gave the lowest values of vitamin $C$ in both seasons. Similar results were obtained by El-Wakeel et al., (2013) and Vijay et al., (2019).

Table 4: Effect of foliar application of different potassium forms on physical fruit quality of Balady mandarin trees

\begin{tabular}{lccccccc}
\hline Treatments & \multicolumn{2}{c}{$\begin{array}{c}\text { Fruit length } \\
(\mathrm{cm})\end{array}$} & \multicolumn{2}{c}{$\begin{array}{c}\text { Fruit diameter } \\
(\mathrm{cm})\end{array}$} & \multicolumn{2}{c}{$\begin{array}{c}\text { Fruit volume } \\
(\mathrm{ml})\end{array}$} \\
\cline { 3 - 8 } & 2019 & 2020 & 2019 & 2020 & 2019 & 2020 \\
\hline \multicolumn{2}{l}{ Control (tap water) } & $5.10 \mathrm{f}$ & $5.22 \mathrm{f}$ & $6.03 \mathrm{~h}$ & $6.17 \mathrm{f}$ & $146.26 \mathrm{e}$ & $149.71 \mathrm{f}$ \\
Potassium & $2 \mathrm{~g} / \mathrm{l}$ & $5.20 \mathrm{e}$ & $5.33 \mathrm{e}$ & $6.15 \mathrm{~g}$ & $6.30 \mathrm{e}$ & $149.14 \mathrm{de}$ & $152.91 \mathrm{e}$ \\
sulphate & $3 \mathrm{~g} / \mathrm{l}$ & $5.31 \mathrm{~d}$ & $5.46 \mathrm{~d}$ & $6.28 \mathrm{f}$ & $6.45 \mathrm{~d}$ & $152.30 \mathrm{~d}$ & $156.48 \mathrm{~d}$ \\
& $4 \mathrm{~g} / \mathrm{l}$ & $5.47 \mathrm{c}$ & $5.58 \mathrm{c}$ & $6.46 \mathrm{e}$ & $6.59 \mathrm{c}$ & $156.71 \mathrm{c}$ & $159.95 \mathrm{c}$ \\
& $2 \mathrm{~g} / \mathrm{l}$ & $5.59 \mathrm{bc}$ & $5.71 \mathrm{~b}$ & $6.60 \mathrm{c}$ & $6.74 \mathrm{~b}$ & $160.12 \mathrm{bc}$ & $163.55 \mathrm{bc}$ \\
Potassium & $3 \mathrm{~g} / \mathrm{l}$ & $5.67 \mathrm{ab}$ & $5.81 \mathrm{a}$ & $6.70 \mathrm{~b}$ & $6.85 \mathrm{a}$ & $162.55 \mathrm{ab}$ & $165.93 \mathrm{ab}$ \\
silicate & $4 \mathrm{~g} / \mathrm{l}$ & $5.75 \mathrm{a}$ & $5.86 \mathrm{a}$ & $6.80 \mathrm{a}$ & $6.92 \mathrm{a}$ & $164.91 \mathrm{a}$ & $167.98 \mathrm{a}$ \\
& $2 \mathrm{~g} / \mathrm{l}$ & $5.48 \mathrm{c}$ & $5.59 \mathrm{c}$ & $6.48 \mathrm{e}$ & $6.60 \mathrm{c}$ & $157.14 \mathrm{bc}$ & $160.20 \mathrm{c}$ \\
Potassium & $3 \mathrm{~g} / \mathrm{l}$ & $5.52 \mathrm{c}$ & $5.65 \mathrm{bc}$ & $6.52 \mathrm{de}$ & $6.66 \mathrm{bc}$ & $158.17 \mathrm{bc}$ & $161.44 \mathrm{c}$ \\
humate & $4 \mathrm{~g} / \mathrm{l}$ & $5.56 \mathrm{c}$ & $5.66 \mathrm{bc}$ & $6.57 \mathrm{~cd}$ & $6.69 \mathrm{bc}$ & $159.40 \mathrm{bc}$ & $162.26 \mathrm{c}$ \\
& & &
\end{tabular}

Means followed by different letter are significantly different within columns by Duncan's multiple range test, $\mathrm{P} \leq 0.05$.

Table 5: Continue the effect of foliar application of different potassium forms on physical fruit quality of Balady mandarin trees

\begin{tabular}{lccccccc}
\hline Treatments & \multicolumn{2}{c}{$\begin{array}{c}\text { Fruit firmness } \\
\text { (Newton) }\end{array}$} & \multicolumn{2}{c}{$\begin{array}{c}\text { Peel thickness } \\
(\mathrm{mm})\end{array}$} & \multicolumn{2}{c}{$\begin{array}{c}\text { Fruit juice } \\
(\%)\end{array}$} \\
\cline { 2 - 8 } & & 2019 & 2020 & 2019 & 2020 & 2019 & 2020 \\
\hline Control (tap water) & & $22.37 \mathrm{~h}$ & $21.42 \mathrm{i}$ & $3.4 \mathrm{a}$ & $3.6 \mathrm{a}$ & $42.31 \mathrm{j}$ & $44.89 \mathrm{i}$ \\
Potassium & $2 \mathrm{~g} / \mathrm{l}$ & $22.81 \mathrm{~g}$ & $21.99 \mathrm{~h}$ & $3.5 \mathrm{a}$ & $3.7 \mathrm{a}$ & $43.23 \mathrm{i}$ & $45.96 \mathrm{~h}$ \\
sulphate & $3 \mathrm{~g} / \mathrm{l}$ & $23.29 \mathrm{f}$ & $22.62 \mathrm{~g}$ & $3.5 \mathrm{a}$ & $3.8 \mathrm{a}$ & $44.46 \mathrm{~h}$ & $47.15 \mathrm{~g}$ \\
& $4 \mathrm{~g} / \mathrm{l}$ & $23.97 \mathrm{e}$ & $23.23 \mathrm{f}$ & $3.6 \mathrm{a}$ & $3.8 \mathrm{a}$ & $45.68 \mathrm{~g}$ & $48.31 \mathrm{f}$ \\
Potassium & $2 \mathrm{~g} / \mathrm{l}$ & $24.49 \mathrm{C}$ & $23.87 \mathrm{c}$ & $3.7 \mathrm{a}$ & $3.9 \mathrm{a}$ & $46.79 \mathrm{c}$ & $49.51 \mathrm{c}$ \\
silicate & $3 \mathrm{~g} / \mathrm{l}$ & $24.86 \mathrm{~b}$ & $24.29 \mathrm{~b}$ & $3.8 \mathrm{a}$ & $4.0 \mathrm{a}$ & $47.57 \mathrm{~b}$ & $50.30 \mathrm{~b}$ \\
& $4 \mathrm{~g} / \mathrm{l}$ & $25.22 \mathrm{a}$ & $24.65 \mathrm{a}$ & $3.8 \mathrm{a}$ & $4.0 \mathrm{a}$ & $48.34 \mathrm{a}$ & $50.98 \mathrm{a}$ \\
Potassium & $2 \mathrm{~g} / \mathrm{l}$ & $24.03 \mathrm{e}$ & $23.27 \mathrm{f}$ & $3.6 \mathrm{a}$ & $3.8 \mathrm{a}$ & $45.83 \mathrm{f}$ & $48.39 \mathrm{f}$ \\
humate & $3 \mathrm{~g} / \mathrm{l}$ & $24.19 \mathrm{de}$ & $23.49 \mathrm{e}$ & $3.7 \mathrm{a}$ & $3.9 \mathrm{a}$ & $46.16 \mathrm{e}$ & $48.80 \mathrm{e}$ \\
& $4 \mathrm{~g} / \mathrm{l}$ & $24.38 \mathrm{~cd}$ & $23.64 \mathrm{~d}$ & $3.7 \mathrm{a}$ & $3.9 \mathrm{a}$ & $46.55 \mathrm{~d}$ & $49.08 \mathrm{~d}$ \\
\hline
\end{tabular}

Means followed by different letter are significantly different within columns by Duncan's multiple range test, $\mathrm{P} \leq 0.05$ 
Influence of foliar sprays of different potassium fertilizers on yield and fruit ......

Table 6: Effect of foliar application of different potassium forms onchemical fruit quality of Balady mandarin trees

\begin{tabular}{|c|c|c|c|c|c|c|c|}
\hline \multirow{2}{*}{\multicolumn{2}{|c|}{ Treatments }} & \multicolumn{2}{|l|}{ TSS $\%$} & \multicolumn{2}{|l|}{ Acidity\% } & \multicolumn{2}{|c|}{ TSS/acidratio } \\
\hline & & 2019 & 2020 & 2019 & 2020 & 2019 & 2020 \\
\hline \multicolumn{2}{|c|}{ Control (tap water) } & $11.84 \mathrm{C}$ & $11.24 \mathrm{~g}$ & $1.08 \mathrm{~d}$ & $1.10 \mathrm{f}$ & $10.96 \mathrm{a}$ & $10.21 \mathrm{abc}$ \\
\hline $\begin{array}{l}\text { Potassiu } \\
\text { m } \\
\text { sulphate }\end{array}$ & $\begin{array}{l}2 \mathrm{~g} / \mathrm{l} \\
3 \mathrm{~g} / \mathrm{l} \\
4 \mathrm{~g} / \mathrm{l}\end{array}$ & $\begin{array}{l}12.06 \mathrm{~b} \\
12.10 \mathrm{ab} \\
12.22 \mathrm{ab}\end{array}$ & $\begin{array}{l}11.49 \mathrm{f} \\
11.75 \mathrm{e} \\
12.01 \mathrm{~d}\end{array}$ & $\begin{array}{l}1.22 \mathrm{abc} \\
1.24 \mathrm{ab} \\
1.27 \mathrm{a}\end{array}$ & $\begin{array}{l}1.24 \mathrm{abc} \\
1.26 \mathrm{ab} \\
1.28 \mathrm{a}\end{array}$ & $\begin{array}{l}9.88 \text { bc } \\
9.75 \text { bc } \\
9.62 \mathrm{c}\end{array}$ & $\begin{array}{l}9.26 \mathrm{~d} \\
9.32 \mathrm{~d} \\
9.38 \mathrm{~d}\end{array}$ \\
\hline $\begin{array}{l}\text { Potassiu } \\
\text { m silicate }\end{array}$ & $\begin{array}{l}2 \mathrm{~g} / \mathrm{l} \\
3 \mathrm{~g} / \mathrm{l} \\
4 \mathrm{~g} / \mathrm{l}\end{array}$ & $\begin{array}{c}12.10 \mathrm{ab} \\
12.16 \mathrm{ab} \\
12.26 \mathrm{a}\end{array}$ & $\begin{array}{l}12.19 \mathrm{bc} \\
12.26 \mathrm{~b} \\
12.32 \mathrm{a}\end{array}$ & $\begin{array}{l}1.14 \mathrm{c} \\
1.17 \mathrm{bc} \\
1.18 \mathrm{bc}\end{array}$ & $\begin{array}{l}1.15 \mathrm{e} \\
1.18 \mathrm{de} \\
1.21 \mathrm{bcd}\end{array}$ & $\begin{array}{l}10.61 \mathrm{ab} \\
10.39 \mathrm{abc} \\
10.40 \mathrm{abc}\end{array}$ & $\begin{array}{l}10.60 \mathrm{a} \\
10.38 \mathrm{ab} \\
10.18 \mathrm{abc}\end{array}$ \\
\hline $\begin{array}{l}\text { Potassiu } \\
\text { m humate }\end{array}$ & $\begin{array}{l}2 \mathrm{~g} / \mathrm{l} \\
3 \mathrm{~g} / \mathrm{l} \\
4 \mathrm{~g} / \mathrm{l}\end{array}$ & $\begin{array}{r}12.08 \mathrm{ab} \\
12.13 \mathrm{ab} \\
12.24 \mathrm{ab}\end{array}$ & $\begin{array}{l}12.03 \mathrm{~d} \\
12.16 \mathrm{c} \\
12.20 \mathrm{bc}\end{array}$ & $\begin{array}{l}1.18 \mathrm{bc} \\
1.22 \mathrm{abc} \\
1.24 \mathrm{ab}\end{array}$ & $\begin{array}{l}1.20 \mathrm{~cd} \\
1.22 \mathrm{bcd} \\
1.24 \mathrm{abc}\end{array}$ & $\begin{array}{l}10.23 a b c \\
9.94 b c \\
9.87 b c\end{array}$ & $\begin{array}{l}10.02 \mathrm{bc} \\
9.96 \mathrm{bc} \\
9.83 \mathrm{c}\end{array}$ \\
\hline
\end{tabular}

Means followed by different letter are significantly different within columns by Duncan's multiple range test, $P \leq 0.05$.

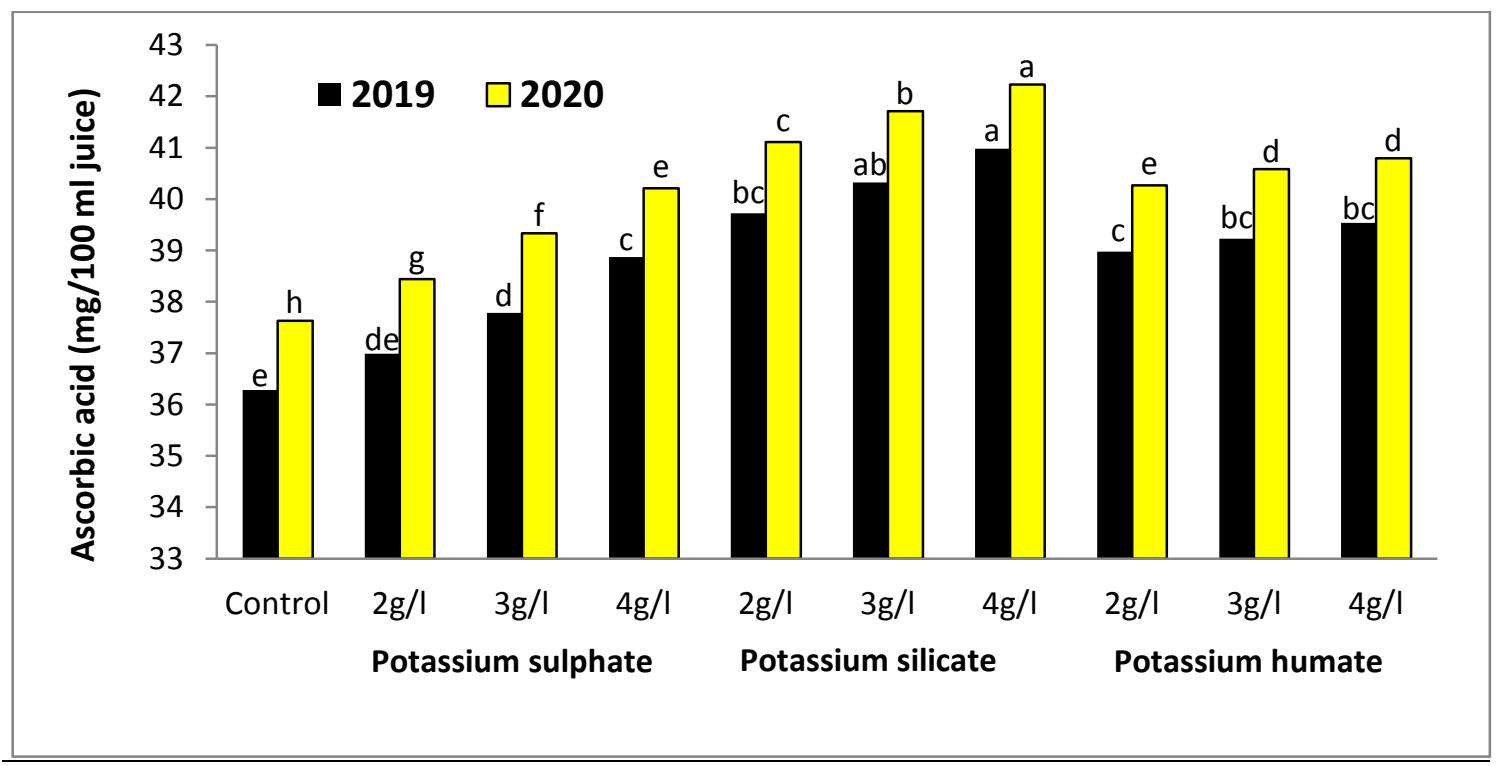

Figure 1: Effect of foliar application of different potassium forms on ascorbic acid $(\mathrm{mg} / 100 \mathrm{ml}$ juice) in fruit of Balady mandarin trees.

Generally, it is obvious from Tables 3, $4,5,6$ and figure 1 that, spraying Balady mandarin trees with potassium silicate, potassium humate and potassium sulphate with the three concentrations increased fruit weight, length, diameter, juice \%, acidity, TSS and vitamin C especially in potassium silicate at 4 and 3 g/l, while, peel thickness was not affected in both seasons. These results reveal a positive relationship that can arise between fruit quality and foliar spray of potassium combined with silicon the present results are in a general harmony with Abd-Elall and Hussein (2018) on Balady orange. 


\section{Conclusion}

It can be concluded from the above results that potassium sprays especially potassium silicate at $4 \mathrm{~g} / \mathrm{l}$ had a positive effect on nitrogen, phosphorus, potassium percentages, total carbohydrate, total chlorophyll contents in the leaves, which reflected on enhanced yield and fruit physical and chemical characteristics compared to control and other treatments. Therefore, it could be recommended that spraying Balady mandarin trees with potassium silicate at $4 \mathrm{~g} / \mathrm{l}$ three times beginning of 15 April, 20 May and 24 June which are considered the best treatment used for improve leaves nutritional status and enhanced yield and fruit physical and chemical characteristics.

\section{REFERENCES}

A.O.A.C. (1990). Association of official analytical chemists.Official Methods of Analysis.15th Ed. Washington D.C., USA.

Abd-Elall, E.H. and M.A. Hussein (2018). Foliar application of micro silica, potassium chloride and calcium chloride enhances yield and fruit quality of Balady orange tree. Alexandria Science Exchange Journal 39(3): 387 - 393.

Abo El-Enien, M.M., A.B. Abo El-Kassim, A.M. El-Azaze and F.S. El- Sayed (2017). Effect of silicon, potassium and calcium compounds on growth and increase the efficiency of citrus seedlings to resist citrus leafminer (Phyllocnistis citrella). J. Product. \& Dev., 22(3): 729 - 749.

Alva, A.K., S. Paramasivam, B. Patil, D. Mattos, Jr., H. Dou, and K.S. Sajwan (2001). Role of potassium on sustainable citrus production. pp. 336339. In Proc. Intl. Symp. Role Pot. Sus. Agric., New Delhi, India.
Alva, A.K., D. Mattos, Jr., S. Paramasivam, B. Patil, H. Dou and K. S. Sajwan (2006). Potassium management for optimizing citrus production and quality. International Journal of Fruit Science, 6(1):3 - 43.

Aly, O.A., A.M. El-Salhy, H.A. Abd-El-Galil and S.M. El-Masry (2011). Effect of different potassium fertilizer forms and antioxidant application on vegetative growth, nutrient status and fruiting of Balady mandarin trees. Assiut J. of Agric. Sci., 42:317 - 331.

Anonymous (2019). Ministry of Agriculture and Land Reclamation, Central Administration of Horticulture and Agricultural Crops, General Administration of Fruit. Annual report of statistics fruit crops in the republic, Cairo, Egypt.

Ashraf, M.Y., A. Gul, M. Ashraf, F. Hussain and G. Ebert (2010). Improvement yield and quality of Kinnow (Citrus deliciosax Citrus nobilis) by potassium fertilization. Journal of Plant Nutrition, 33(11):1625 $-1637$.

Brown, J.D. and O. Lillelland (1974). Rapid determination of potassium and sodium in plant material and soil extracts by flame photometer. Proc. Soc. Hort. Sci., 48: 341-346.

Dubois, M., A. Gilles, J.K. Hamiltom, P.A. Rebers and F. Smith (1956). Colorimetric method for determination of sugars and related substances. Analytical Chemistry 28(3):350-356.

Duncan, D. B. (1955). Multiple ranges and multiple F test. J. Biometrics, 11: 1-42.

El-Mahdy, T.K., M.M. Abdel-Salam, R.A. Ibrahim and M.A. Mahmoud (2019). Effect of different levels of potassium fertilizer on yield and fruit quality of old trees of "Balady" orange. A: Effect of different levels of potassium fertilizer on some physical properties and yield parameters of "Balady" 
orange. Assiut J. Agric. Sci., 50(1): 97 $-106$.

El-Saady, A.S.M. and A.A. El-Abd (2012). Effect of balanced fertilizer splitting on navel orange yield and fruit quality. J. Soil Sci. and Agric. Eng., Mansoura Univ., 3(1): 41 - 51.

El-Salhy, A.M., H.A. Abdel-Galil, E.F.M. Badawy and E.A.A. Abou-Zaid (2017). Effect of different potassium fertilizer sources on growth and fruiting of Balady mandarin trees. Assiut $J$. Agric. Sci., 48(1-1): $202-213$.

El-Wakeel, H.F., N. Mansour, M. Mubarak and E.A. Hassan (2013). The response of bearing navel orange trees to some sources and rates of potassium fertilizers and silicate bacteria. Journal of Applied Sciences Research, 9(11):5780 - 5793.

Ennab, H.A., S.A. El-Sayed and M.M. Abo El-Enin (2017). Effect of kaolin applications on fruit sunburn, yield and fruit quality of Balady mandarin (Citrus reticulata, Blanco).Menoufia $\mathrm{J}$. Plant Prod., 2: 129 - 138.

Evenhuis, B. and P.W. Dewaard (1980). Principles and practices in plant analysis. FAO soils Bull. 38:152-163.

Hamza, A., A. Bamouh, M. El Guilli and R. Bouabid (2015). Response of Cadoux Clementine to foliar potassium fertilization: Effects on fruit production and quality. Acta Hort., 1065:1785 - 1794.

Hasanuzzaman, M., M. H. Bhuyan, K. Nahar, S. Hossain, J. Al Mahmud, S. Hossen, A.A. Masud, A.C. Moumita and M. Fujita (2018). Potassium: A vital regulator of plant responses and tolerance to a biotic stresses. Agronomy 8: 31; doi: 10.3390/ agronomy 8030031

Iglesias, D.J., M. Cercos, J.M. ColmeneroFlores, M.A. Naranjo, G. Rios, E. Carrera, O. Ruiz-Rivero, I. Lliso, R. Morillon, F.R. Tadeo and M. Talon
(2007). Physiology of citrus fruiting. Brazilian Journal of Plant Physiology, 19(4): 333 - 362.

Kumar and M. Kavino (2006). Role of potassium in fruit crops - a review. Agric. Rev., 27 (4): $284-291$.

Mostafa, E.A.M. and M.M.S. Saleh (2006). Response of Balady mandarin trees to girdling and potassium sprays under sandy soil conditions. Research Journal of Agriculture and Biological Sciences, 2(3): 137 - 141.

Murphy, J. and J.R. Riley (1962). A modified single solution method for the determination of phosphorus in natural water.Anal. Chem., Acta, 27: 31-38.

Netto, A.T., E. Campostrini, J.G. Oliveira and R.E. Bressan-Smith (2005). Photosynthetic pigments, nitrogen, chlorophyll a florescence and SPAD readings in coffee leaves. Scientia Hort., 104: 199 - 209.

Quaggio, J.A., D.M. Junior and R.M. Boaretto (2011). Sources and rates of potassium for sweet orange production. Sci. Agric. (Piracicaba, Braz.), 68(3): 369 - 375.

Reetika, G., S. Rana, R. Kumar and R. Kumar (2020). Impact of foliar fertilization on leaf nutrient status of Kinnow mandarin. International Journal of Plant \& Soil Science 32(8):8 $-14$.

Sarrwy, S.M.A., M.H. El-Sheikh, S.S. Kabeil and A. Shams El-Din (2012). Effect of foliar application of different potassium forms supported by zinc on leaf mineral contents, yield and fruit quality of "Balady" mandarin trees. Middle-East J. Sci. Res., 12 (4): 490 498.

Shaaban, E.A., M.S. El-Shamma, S. EI Shazly, A. El-Gazzar and R.E. AbdelHak (2012). Efficiency of rock-feldspar combined with silicate dissolving bacteria on yield and fruit quality of 
Valencia orange fruits in reclaimed soils. Journal of Applied Sciences Research, 8(8):4504 - 4510.

Shen, C., Y. Ding, X. Lei, P. Zhao, S. Wang, Y. Xu and C. Dong (2016). Effects of foliar potassium fertilization on fruit growth rate, potassium accumulation, yield, and quality of 'Kousui' Japanese pear. Hortechnology 26(3):270 - 277.

Snedecor, G.W. and W.G. Cochran (1990). Statistical methods.7th Ed. lowa State Univ. Press. Ames., lowa, USA, p. 593.

Taha, R.A., H.S.A. Hassan and E.A. Shaaban (2014). Effect of different potassium fertilizer forms on yield, fruit quality and leaf mineral content of Zebda mango trees. Middle-East Journal of Scientific Research 21(1): $123-129$.

Vijay, D.R., B. S. Beniwal and H. Saini (2017). Effect of foliar application of potassium and its spray schedule on yield and yield parameters of sweet orange (Citrus sinensis Osbeck) cv. Jaffa. Journal of Applied and Natural Science 9 (2): 786 - 790.

Vijay, D.R., S.H. Saini and V. Sheoran (2019). Influence of foliar application of potassium and its spray schedule on quality, yield and nutrient content of leaf in citrus. International Journal of Chemical Studies 7(1):853-861.

Wang, M., Q. Zheng, Q. Shen and S. Guo (2013). The critical role of potassium in plant stress response. International Journal of Molecular Sciences 14(4): 7370 - 7390.

Zaghloul, A.E. and R.E. Knany, R.E. (2012). Effect of balanced fertilization and fertilizer levels on navel orange yield and fruit quality. Alexandria Science Exchange Journal 33(1): 44 54. 
تأثير الرش الورقى لأسمدة البوتاسيوم المختلفة على محصول و جودة ثمار اليوسفى البلدى

\author{
حسن أبو الفتوح عناب ، عبد الفتاح منتصر عبدالسلام خضر

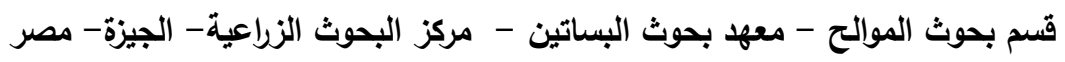

الملخص العربى

أجريت هذه الدراسة على أشجار يوسفي بلاي عمرها عشرين عاما والمزروعة في مزرعة خاصة بمركز مطويس -

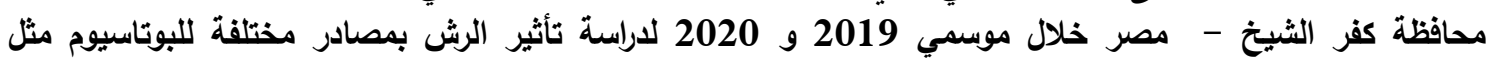

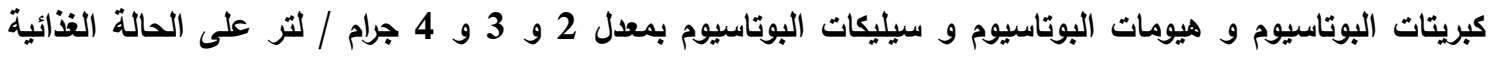

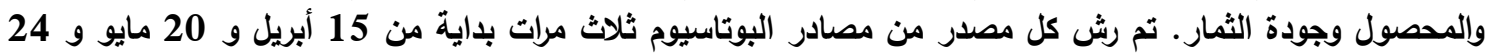
يونيو.

أظهرت النتائج أن رش البوتاسيوم وخاصة سيليكات البوتاسيوم عند 4 جرام / لتر كان له تأثير إيجابي على تركيز

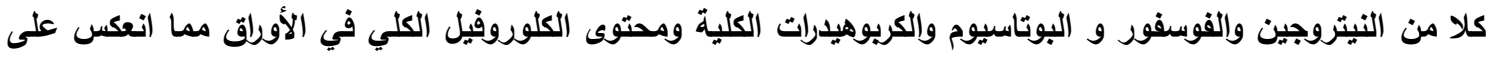

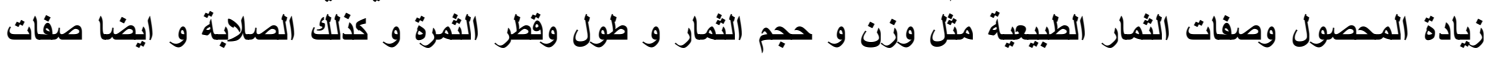

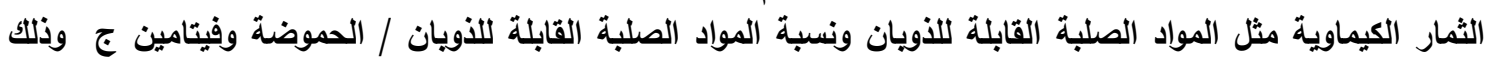
عند المقارنة مع الكتترول و المعاملات الأخرى.

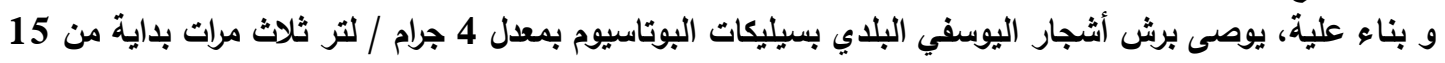

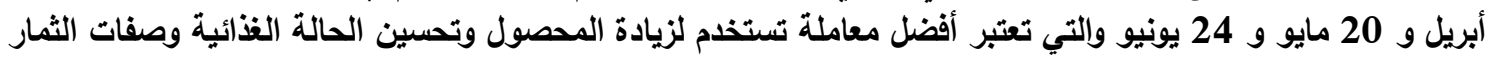
الطبيعية و الكميائية. 